skill. In addition, independent climate information sources from various areas, which are not included in the reconstructions, are consistent with the reconstructed temperature and precipitation patterns.

As expected, the reconstruction of the Atlantic SSTs, based on remote tree-ring data from America, Europe and Morocco, reveals only small areas with some reconstruction skill (positive RE-values). These results indicate that the reconstructed SSTs should not be over-interpreted and that more accurate predictors for the reconstructions of this variable have to be found.

\section{Conclusions and outlook}

Reconstruction of European climatic variables over the last few centuries is made possible by the specific combination of data from documentary sources, natural archives and early instrumental measurements. Without documentary data, a satisfactory spatial resolution cannot be achieved for periods when instrumental data are lacking. Thus, they provide an important base for the reconstruction of processes responsible for the strong climate fluctuations in Europe during the second half of the Little Ice Age. We took the first step of developing temporally and spatially highly resolved histories for several climate variables in the past. Such histories are required in order to facilitate the search for an unambiguous 'fingerprint' of recent climate response to increasing greenhouse gas emissions. We therefore hope that our preliminary 'paleorenalysis' results, alongside long-term hindcast runs of coupled general circulation models, will provide a better understanding of the underlying processes associated with both natural and anthropogenic climate change. A question that merits further discussion is whether or not it would make sense to start an initiative to produce a more comprehensive paleoreanalysis product based on further European, or even global, multi-proxy data.

\section{ACKNOWLedgements}

The authors wish to thank Rudolf Brázdil and Mariano Barriendos for providing temperature and precipitation indices for the Czech Republic and Spain. The whole ADVICE, IMROVE, WASA and ALOCLIM projects consortium is acknowledged for the use of their homogenised data.
We wish to express our thank also to Ed Cook and Mary Glueck for providing their tree-ring data and Alexey Kaplan for the use of SST data. The gridded temperature and precipitation data has been supplied by the Climate Impacts LINK Project (UK Department of the Environment Contract EPG 1/1/16) on behalf of the Climatic Research Unit, University of East Anglia. Elena Xoplaki is acknowledged for drawing the figure.

\section{REFERENCES}

Kaplan, A., Cane, M., Kushnir, Y., Clement, A., Blumenthal, M. and Rajogopalan, B., 1998: Analyses of global sea surface temperature 1856-1991, Journal Geophysical Research, 103, 18567-18589. Luterbacher, J., Xoplaki, E., Dietrich, D., Rickli, R., Jacobeit, J., Beck, C., Gyalistras, D., Schmutz, C. and Wanner, H., 2002: Reconstruction of Sea Level Pressure fields over the Eastern North Atlantic and Europe back to 1500, Climate Dynamics, 18, 545-561.

Mann, M.E., Bradley, R.S. and Hughes, M.K., 1998 Global-scale temperature patterns and climate forcing over the past six centuries, Nature, 392 779-787.

New, M., Hulme, M. and Jones, P.D., 2000: Representing Twentieth-Century space-time climate variability. Part II: Development of 1901-1996 monthly grids of terrestrial surface climate, Journal of Climate, 13, 2217-2238.

Trenberth, K. and Paolino, D.A., 1980: The Northern Hemisphere sea-level pressure data set: trends, errors and discontinuities, Monthly Weather Review, 108, 855-872

\title{
The Potential of Archival Sources for Reconstructing Climate and Climate-Related Processes in Latin America
}

\author{
S.e. Metcalfe ${ }^{1}$, M.del R. Prieto ${ }^{2}$, G.H. Endfield ${ }^{3}$, S.J. Davies ${ }^{4}$, S.L. 0'Hara ${ }^{2}$ \\ ${ }_{1}^{1}$ Geography, School of Earth, Environmental and Geographical Sciences, University of Edinburgh EH8 9XP, UK; sem@ossian.geo.ed.ac.uk \\ 2Unidad de Historia Ambiental, Instituto Argentino de Nivologia, Glaciologia y Ciencias Ambientales, 5500 Mendoza, Argentina; \\ mrprieto@lab.cricyt.edu.ar, ohara@geography.nottingham.ac.uk \\ 3 School of Geography, University of Nottingham, Nottingham NG7 2RD, UK; Georgina.Endfield@nottingham.ac.uk \\ ${ }^{4}$ Institute of Geography and Earth Science, University of Wales, Aberystwyth SY23 3DB, UK; sjd@aber.ac.uk
}

Following the conquest of Mexico and large portions of Central and South America in the $16^{\text {th }}$ century, the Spanish Colonial administration began compiling documents on population, settlements, landscapes and economic resources. Combined with the collections of judicial documents including law suits and land grants, the various pictographic, ethnohistorical sources dating back to the pre- and early post-Conquest period and the scientific reports and travelogues of visitors, this archival legacy represents an incredibly rich media of documentary information (e.g. Butzer and Butzer, 1997. The climatic information within the various archival and documentary sources can generally be divided into a number of categories. The first includes direct, dated descriptions and accounts of catastrophic, extreme or damaging, and hence noteworthy climate events such as hurricanes, frosts, droughts or floods. The second includes general anecdotal observations of contemporary climatic conditions, such as the early or late arrival of the summer rainy season, unusually dry or wet conditions and the implications this had particularly for agricultural communities. The third comprises indirect evidence, where the reporting of a climate event per se was not the main purpose of the document. This category might include references to harvest gains or losses, crop blights, disputes over changes in availability of and access to water sources and descriptions of the physical impact of climate change on the landscape as recorded in written descriptions, maps, drawings (pinturas) or photographs.

During the Colonial period a vast quantity of documents from the various levels of the Spanish administration, accumulated in local, regional and national Archives. Documents were also preserved in Spain itself in the Archivo de Indias in Seville and other Spanish archives. The single most important archive in Mexico is the Archivo General de la Nación (AGN) in Mexico City, home to by far 


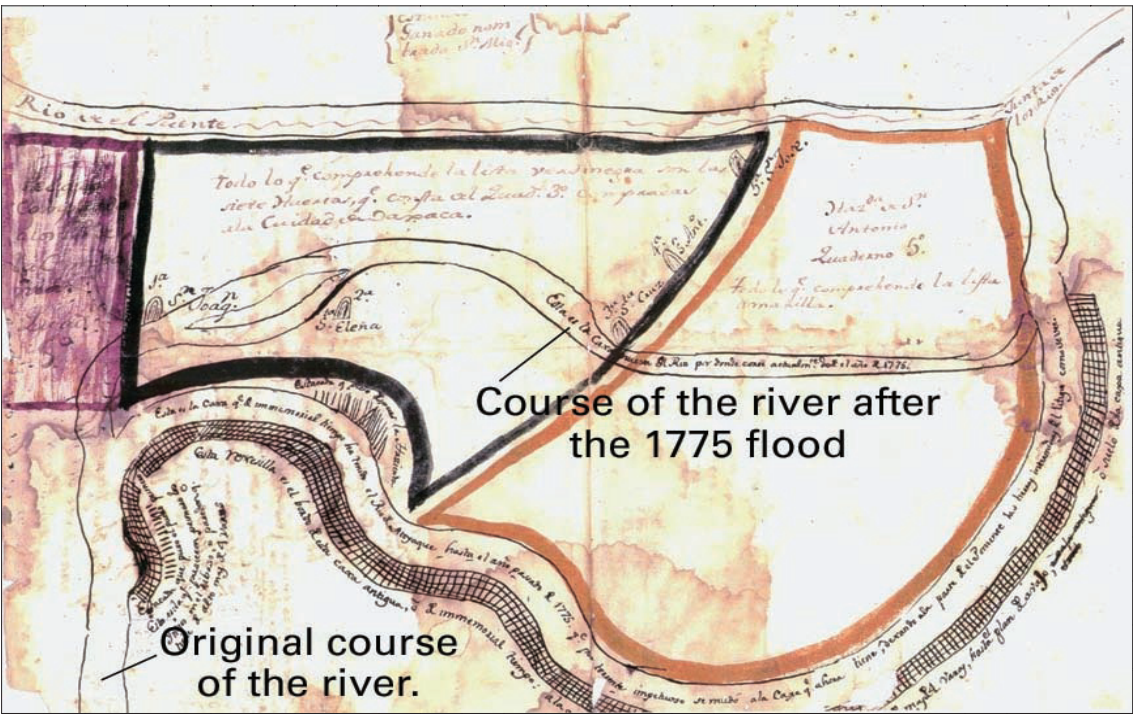

Fig. 1: Map illustrating channel migration of the Rio Atoyac, Oaxaca, Mexico following a flood event in 1775 (Archivo Privado de Don Luis Casteñada Guzman, Oaxaca).

the richest archival collection on the history of the Americas. There are in total 115 ramos (document groups) consisting of over 300,000 individual documents dealing with Colonial New Spain alone now comprehensively indexed on a CD-ROM. The state, regional and municipal level archival repositories, the various archival collections of the different branches of the church and the many private archives across Mexico provide an equally valuable, but under exploited, reserve useful for climate historians. The geographical descriptions (Relaciones Geograficas) of the different regions of Mexico undertaken in the late $16^{\text {th }}$ and late $18^{\text {th }}$ century provide location and period specific information. Other descriptions, accounts and reports such as those provided by travellers, missionaries and scientists who visited the different regions of Mexico also include references to climate characteristics and events.

Among the essential sources for the history of climate in Latin America are the Actas Capitulares which recorded the Cabildo (Mayoralty) activities in the colonial cities on a weekly basis. The climatic phenomena occurring during the week were written down, especially those that had adverse economic consequences, like droughts and floods. Their characteristic is their continuity through time and their homogeneity. The Actas from the cities of Santiago de Chile and Buenos Aires were published in their en- tirety at the end of the $19^{\text {th }}$ century. Potosi has an exceptional collection of Actas extending back to 1585 , but they remain unpublished. In Chile and Argentina, southern areas were colonised later than the north, the coastal areas first and later the Andean zones. The scarce information from before the $19^{\text {th }}$ century comes from those coastal cities and from the chronicles written by the priests travelling across the region.

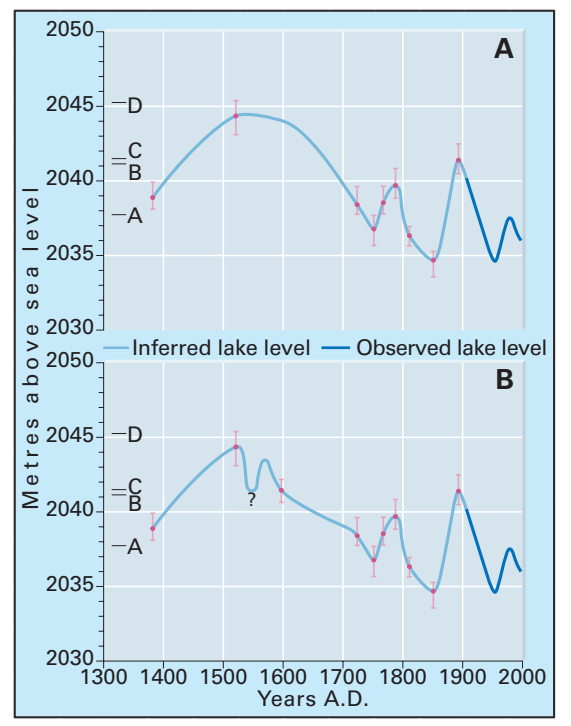

Fig. 2: Changes in the level of Lake Pátzcuaro, Mexico since ca. 1380. A) original figure from O'Hara 1993 (The Geographical Journal, $159,51-62), B)$ revised figure based on more recent archival searches. Letters $A$ to $D$ refer to reference points in the basin: Copujo only exists as an island with lake level between $A$ and $B$. Apupuato becomes an island when the lake stands above $C$, below this level it is connected to the mainland. When lake level rises above D, Tzentzencuaro becomes an island.

\section{Direct meteorological observations}

The first systematic records of climatic variables were made in Mexico in the second half of the $18^{\text {th }}$ century. Most early records are for precipitation only, but regular reports of temperature and precipitation were published in the Mexico City newspaper, El Sol, from 1826. The Central Meteorological Observatory was established in 1877 and a national network of meteorological stations was instigated. The Servicio Meteorologico de Mexico was founded in 1921. The collection of meteorological data was severely disrupted in the period leading up to and during the Mexican revolution (1917). The longest single record comes from the Tacubaya Observatory in Mexico City (started 1884, extended by interpolation to 1877). In Chile and Argentina amateurs systematically recorded temperature, rainfall and other meteorological phenomena in the $19^{\text {th }}$ century, in spite of civil wars and political anarchy. In Mendoza this started in 1823. In the city of La Paz, Bolivia, the most important meteorological records were compiled by the Jesuits, who recorded the weather in San Calixto de La Paz from 1891 until the present day. Meteorological offices began in Argentina and Chile in the last quarter of the $19^{\text {th }}$ century. The province of Buenos Aires was a pioneer, having a meteorological observatory from the middle of the $19^{\text {th }}$ Century. Newspapers began reporting weather phenomena around 1850.

\section{Mexico}

Investigations have highlighted the potential of various ramos in the AGN dealing with crops and harvests as indices of climatic variability. Drought histories have been reconstructed based on crop prices, harvest records (e.g Alhondígas) and newspaper reports (Gazeta de Mexico) and on correspondence between hacienda administrators (Archivo de la Historia de la Hacienda) in the Basin of Mexico (Florescano and Swan, 1995). Extensive archival analyses of litigation documents have highlighted a potential correlation between increased legal 
conflict over the use of and access to water sources and periods of drought (Endfield and O'Hara, 1997). Judicial documents dealing with land grants (Mercedes) and law suits over land and water (Tierras) are among the most useful archival sources for climate historians. Such documents often include descriptions of changes in hydrological regimes or vegetation related to climate.

Historical maps and pinturas have long been used in the reconstruction of regional environmental histories in Mexico, but can also provide useful information on past climatic conditions and the impacts of specific climate events. A map taken from a private archive in Oaxaca, drawn to illustrate changes in property boundaries, shows the impacts of an extreme flood event in 1787 on a river channel (Fig. 1). The form of the river channel before and after the event is illustrated and described with written annotation.

Law suits over submerged tracts of land, coupled with historical maps, postcards, photographs, oral histories and instrumental records have been used to reconstruct fluctuations in lake levels indicative of climate change. Changes in the level of Lake Pátzcuaro in Michoacán were reconstructed by Sarah O'Hara from $1300 \mathrm{AD}$ to the present day (Fig. 2). Additional archival research, primarily using information derived from law suits held in the Archivo de las Notorias, Morelia, Michoacán, (Tierras y Aguas) has helped to refine this lake level curve, with instrumental records covering the period since 1949.

\section{Southern South America}

In southern South America (Cono Sur), the conquest began at almost the same time in the Rio de la Plata area of Argentina (1536-1537) and Perú ( 1532-1535), continuing into Bolivia (1538) and Chile (1545). In South America there is more climatic information for the colonial period $\left(16^{\text {th }}-18^{\text {th }}\right.$ centuries $)$, than for the $19^{\text {th }}$ century. When those cities with archives had been headquarters of the viceroyship, gobernaciones or corregimientos, there can be a huge quantity of climatic information. This

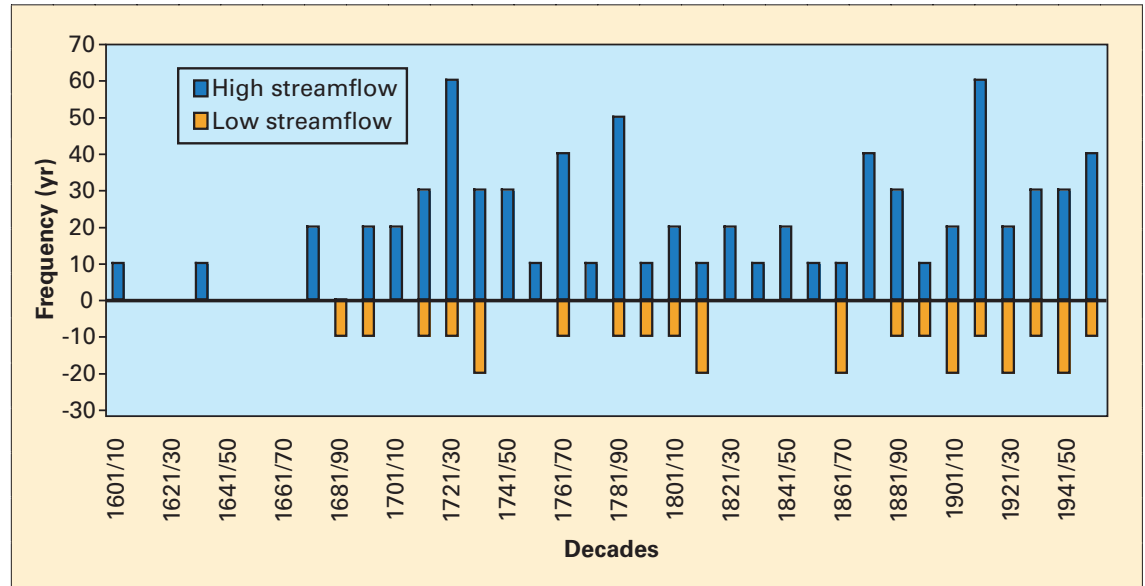

Fig. 3: Reconstructed percentage occurrence of high and low streamflow, by decade, for Mendoza, Argentina for the period 1601 - 1960.

is the case for Buenos Aires, headquarters of the Virreinato del Río de la Plata (1776) or Santiago, headquarters of the Capitanía General de Chile. The Archivo Histórico Nacional de Chile is the most complete in the country. In Argentina, the Archivo General de la Nación contains the largest amount of information. For Bolivia, documents can be found in the Archivo Nacional de Bolivia in Sucre, and in other regional archives such as Oruro and Potosi. There are also collections in monasteries and convents. In Argentinian Patagonia, systematic information starts as late as 1879.

The archives are organized by sections. In the colonial section, the holdings of correspondence are particularly significant. Extreme climatic events affecting the regional economy such as droughts, floods or abundant precipitation, were reported in letters, notes and reports to the Spanish Crown. In other sectors, account books or books on harvests expenditures, instructions about food supplies, compilations of agricultural and cattle prices, can be examined. There are also specific reports on climatic events such as the "Semestral Relations of waters, harvests and other particulars" from the end of the18th century onwards. These provide direct data on climate and agriculture, primarily for Argentina, Bolivia and Paraguay between 1784 and 1810. Annals, chronicles or diaries from priests, religious orders, the military or individuals, complete the range of climatic information.

In Mendoza, Argentina the Actas Capitulares and other sources have been used to reconstruct variations in temperature and precipitation during the $17^{\text {th }}$ and $18^{\text {th }}$ centuries (Prieto et al. 2000) and the Mendoza River streamflow over 350 years (Fig. 3). At Potosí, where mining depended on water resources, dry years were recorded. In Santiago it is possible to find data about floods and heavy rains that devastated the central region of Chile.

The arrival of naturalists, scientists and explorers increased the amount of information for the south of South America. New settlers also made a significant contribution.

\section{Conclusions}

Many different types of information can be used to reconstruct quite detailed records of climatic change over the historical period. Indeed, records derived from crop prices, lake level changes and anecdotal information in the highlands of central Mexico illustrate that annual rainfall in central Mexico has varied considerably over the course of the past 600 years. (O'Hara and Metcalfe, 1995) These data can be integrated with the early instrumental record to provide continuity through to the present day.

The reliability of the data derived from archival sources, however, warrants scrutiny. Unusual weather was, by definition, more noteworthy than normal weather conditions. Historical documents thus tend to be biased towards describing and depicting anomalous and extreme climate events. Archival reconstructions may thus seem to illustrate a society more sensitive and poorly adapted to climatic events than it ac- 
tually was. Moreover, though many of the documents represent the reporting of events and experiences as they took place, they also reflect the positionality, and purpose of the author and the intended audience. Subjectivity and bias will also influence the validity of the information conveyed and used for constructing climatic chronologies. It is difficult to establish from documentary sources, for instance, what constituted normal climatic conditions. There may also be some cases (for example during political upheavals) when unusual climate goes unreported in either the documentary or instrumental record. Whether a climate event is recorded is also dependent on the size of the potentially affected population and its level of economic development.
Climatically-induced agricultural failure, for instance, is only likely to be recorded if a significant number of people are affected by harvest losses. It is also likely that the frequency of singular events might be relatively under recorded in comparison with recognised severe climatic phases, where bad conditions persist over several years.

Such interpretative problems can compromise the value of archival records of climate change. The collections of historical documents available for Latin America as a whole are extremely rich and diverse. Used carefully, these archives can provide us with an invaluable and as yet still under-exploited medium for the reconstruction of detailed regional climate histories.

\section{REFERENCES}

Butzer, K.W. and Butzer, E.K., 1997: The 'natural' vegetation of the Mexican Bajio: archival documentation of a 16th-century savanna environment. Quaternary International 43/44, 161-172.

Endfield, G.H. and O'Hara, S.L., 1997: Conflicts over water in 'The Little Drought Age' in Central Mexico. Environment and History 3, 255-272.

Florescano, E. and Swan. S., 1995: Breve historia de la sequía en México. Universidad Veracruzana, Xalapa.

O'Hara, S.L. and Metcalfe, S.E., 1995: Reconstructing the climate of Mexico from historical records. The Holocene 5, 485-490.

Prieto, M., R. Herrera and Dussel, P., 2000: Archival evidence for some aspects of historical climate variability in Argentina and Bolivia during the 17th and 18th centuries. In: Southern Hemisphere Paleoand Neoclimates. W. Volkheimer and P. Smolka (eds). Springer -Verlag, Berlin-Heidelberg, $381 \mathrm{p}$.

Quinn, W.H., V.T. Neal and Antúnez de Mayolo., S., 1987: El Niño occurrences over the past four and a half centuries

\title{
ENSO Reconstruction Based on Documentary Data From Ecuador, Peru and Chile
}

\author{
Luc 0rtlieb 1 , Gabriel Vargas ${ }^{2}$ and AnNe-Marie Hocouenghem 3 \\ 1 UR PALEOTROPIOUE, IRD, Bondy (France); Luc.Ortlieb@bondy.ird.fr \\ ${ }^{2}$ Depto. de Geología, Universidad de Chile \& UR PALEOTROPIQUE, Santiago (Chile); gvargas@ing.uchile.cl \\ ${ }^{3}$ CNRS \& IRD, Institut Français d'Etudes Andines, Lima (Peru); amhocquenghem@terra.com.pe
}

The first chronology of ENSO occurrences in the past centuries was based on documentary data from South America. A review of the sources and a closer look at the geographical distribution of ENSO impacts across the subcontinent revealed that the sequences of $\mathrm{El}$ Niño events previously proposed (Quinn, 1987) should not be used for calibration purposes until a better knowledge of the regional impacts of ENSO is obtained. On-going research on documentary sources from central Chile and Peru suggests that the current teleconnection patterns were different prior to the early $19^{\text {th }}$ century. If correct, this hypothesis may have important consequences for understanding multidecadal and century-scale ENSO dynamics.

\section{Quinn's historical sequence of El Niño events}

The El Niño phenomenon was defined in 1891, in northern Peru, as a combination of anomalously warm sea temperature, stronger than usual southward coastal current and high rainfall in the Sechura desert. In successive works (Quinn et al., 1987;
Quinn \& Neal, 1992; Quinn, 1993), Quinn proposed a chronological sequence of EI Niño events, covering the last $41 / 2$ centuries, with an individual strength evaluation and confidence rating of every episode. In his last reconstructions, Quinn incorporated more data from Chile and Brazil than from Peru. In his last published work (1993), he also considered a series of documentary and hydrological proxies from the western Pacific and Indian ocean regions, and proposed a global ENSO sequence to be compared with his "regional" (= South American) El Niño sequence (see Fig. 1, left column).

Quinn's sequences have been considered the major reference for most studies of variability in ENSO recurrence and intensity throughout the last four and a half centuries. However, a close re-examination of the same documentary data used by Quinn, and/or additional documents, from Peru, showed that serious doubts must be expressed regarding the real occurrence of a number of these reconstructed EI Niño events (Ortlieb, 2000). In some cases, there were misinterpretations of written data or problems of unreliability of the sources used by Quinn. In other cases, strong documentary evidence from northern Peru and southern Ecuador contradicts the reconstruction of so-called El Niño events (see below). Additionally, in numerous instances, Quinn interpreted occurrences of EI Niño events solely from information on heavy rainfalls in central or southern Peru, or in Bolivia (Potosi), or from a single source. These are areas where precipitation excess cannot be reliably linked to EI Niño conditions even in the modern instrumental period.

\section{Western South America: a key region for ENSO reconstructions} The Pacific coast of South America is undoubtedly a key area for paleoENSO studies, both because of the availability of written records since 1525 AD and because of the strong impact of the ENSO phenomenon in two specific regions.

Analyses of instrumental data of the $20^{\text {th }}$ century confirm that the positive rainfall anomalies over the coastal regions of Ecuador and northern Peru 